\title{
Upregulation of the antiapoptotic factor Livin contributes to cisplatin resistance in colon cancer cells
}

\author{
Zhen-Yu Ding, Gui-Hong Liu, Birgit Olsson and Xiao-Feng Sun
}

\section{Linköping University Post Print}

\section{Tweet}

N.B.: When citing this work, cite the original article.

The original publication is available at www.springerlink.com:

Zhen-Yu Ding, Gui-Hong Liu, Birgit Olsson and Xiao-Feng Sun, Upregulation of the antiapoptotic factor Livin contributes to cisplatin resistance in colon cancer cells, 2013, Tumor Biology, (34), 2, 683-693.

http://dx.doi.org/10.1007/s13277-012-0596-8

Copyright: Karger / Springer Verlag (Germany) http://www.springerlink.com/?MUD=MP

Postprint available at: Linköping University Electronic Press http://urn.kb.se/resolve?urn=urn:nbn:se:liu:diva-96160 


\title{
Up-regulation of the anti-apoptotic factor Livin contributes to cisplatin resistance in colon cancer cells
}

\author{
Zhen-Yu Ding, ${ }^{1,2}$ Birgit Olsson, ${ }^{1}$ Xiao-Feng Sun ${ }^{1}$ \\ ${ }^{1}$ Division of Oncology, Department of Clinical and Experimental Medicine, Faculty of Health Sciences, \\ Linkoping University, Linkoping, Sweden \\ ${ }^{2}$ Cancer Center, the State Key Laboratory of Biotherapy, West China Hospital, West China Medical School, \\ Sichuan University, Chengdu, China \\ Correspondence to: Division of Oncology (O-house, entrance 33 or 34, plan 10, CKOC-stab), Department of \\ Clinical and Experimental Medicine, Faculty of Health Sciences, University of Linköping, S-581 85 Linköping. \\ Tel: +46-(0)10-1032066 \\ Fax: +46-(0)10-1033090 \\ e-mail: xiao-feng.sun@liu.se
}


Abstract The anti-apoptotic factor Livin has been considered critical for tumor progression and poor prognosis for variant types of tumors. But there are only limited reports regarding its expression and biological functions in colon cancer. Here we examined Livin expression in four colon cancer cell lines (HCT116, RKO, KM12C and SW620) in the presence or absence of cisplatin which was used as a model reagent. We found the different response to cisplatin was related to endogenous Livin expression level. From among a panel of apoptosis-related factors (p53, Bcl-2, Bcl-XL, BAX, and survivin), the expression of Livin was up-regulated after cisplatin treatment in a dose-dependent manner. Both the immunocytochemistry and nuclear cytoplasmic fractionation indicated Livin remained in the cytoplasm after treatment with cisplatin. In an attempt to explore the mechanism, we found the elevated expression of Livin was not due to the decreased degradation by proteosome but was enhanced at the mRNA level. Besides, cisplatin treatment activated the mammalian target of rapamycin (mTOR) pathway as shown by increased phosphorylation of Akt1, mTOR, S6K, and 4E-BP1, together with the elevated Livin. The PI3K inhibitor LY294002 inhibited both the phosphorylation of mTOR and up-regulation of Livin. The stable over-expression of Livin inhibited the activation of caspase-3 and led to resistance to cisplatin, while the knock-down of Livin by siRNA rendered colon cancer cells more sensitive to cisplatin. Our study along with others highlighted the potential of Livin for cancer therapy in colon cancer.

Key words: Livin, apoptosis, cisplatin, colon cancer 


\section{Introduction}

Key mediators in apoptosis regulation are of intense biological interest. Inhibitor of Apoptosis (IAP) family of proteins was discovered as endogenous caspase inhibitors to inhibit apoptosis induced by a variety of stimuli [1]. Livin has been identified as a member of the IAP family [2-4]. Its expression spectrum includes melanoma, leukemias, bladder cancer, breast cancer, cervical cancer, nasopharyngeal cancer and lung cancer [5-8]. Interestingly, its expression is hardly detectable, or present at substantially lower levels, in the normal tissue [9]. Two splicing variants have been identified (designated $\alpha$ - and $\beta$ - isoforms) for Livin, which are almost identical except for a 54 bp truncation in exon 6 [10]. The overexpression of both isoforms blocks apoptosis induced by TNF- $\alpha$ and anti-CD95 antibody. It was proposed that Livin could inhibit apoptosis by binding and suppressing downstream caspases through its Baculoviral IAP Repeat domain [3-4], but this is still controversial [11].

Another report awaiting for further confirmation argued that inhibition of apoptosis by Livin might involve the TAK1/JNK1 pathway [12]. Also, Livin could bind and degrade Second Mitochondrial Activator of Caspases (SMAC) through its C-terminal ring zinc-finger (RING) domain [13]. This may further contribute to its anti-apoptotic function.

CRC is one of the leading causes of cancer death in Western countries [14, 15]. And platinum based compounds represent one of the main therapeutic options for solid tumors. Cisplatin (cis-diammine-dichloro-platinum) is widely used as a DNA-damaging drug in this category. It interacts with DNA, resulting in the formation of DNA adducts, primarily intrastrand crosslinks [16]. Subsequently, it induces DNA damage recognition proteins to signal to downstream effectors such as p53, resulting in cell cycle arrest and apoptosis. To date, little is know on the Livin expression profile in CRC except for preliminary reports [17-21]. Neither is it known about the relationship between Livin expression and cisplatin sensitivity in CRC. In this study, we attempted to clarify the mechanisms behind the effects of Livin on cisplatin treatment in CRC 
cells with respect to apoptosis.

\section{Materials and methods}

Plasmid Constructions

The full-length cDNA of Livin was amplified from total RNA isolated from fresh tissue of a metastatic malignant melanoma by RT-PCR with the following primers:

5'-AATAGATCTCATGGGACCTAAAGACAGTGCC-3' (sense) and 5'-AATGGATCCGGACAGGAAGGTGCG-3' (antisense). When the product of the expected size was obtained, it was inserted into UA cloning vector pDrive (Qiagen, Valencia, USA) and then subcloned into pcDNA 3.1 (Invitrogen, Calsbad, USA) to obtain the expression plasmid. The construct was verified by sequencing.

Reagents and Cells

Cytotoxic drug cisplatin, caspase-3 inhibitor z-DEVD-fmk, the colorimetric caspase-3 substrate z-DEVD-pNA, proteosome inhibitor MG-132, protein synthesis inhibitor actinomycin D, antibiotic Geneticin, and dual inhibitor for PI3K and mTOR LY294002 were all purchased from Sigma (Sigma-Aldrich, Stockholm, Sweden). Stock preparation of the reagents was stored at $-20^{\circ} \mathrm{C}$ until use.

Human colon cancer cell lines HCT-116, RKO, SW620 and human embryonic kidney (HEK) cells were from the American Type Culture Collection (ATCC). Human colon cancer cell line KM12C was kindly gifted from Professor IJ Fidler (Anderson Cancer Center, TX, USA). All cells were maintained in Minimal Essential Medium (Sigma-Aldrich) supplemented with 10\% FBS (GIBCO, Invitrogen, Carlsbad, USA), 1.5 mM L-glutamine (GIBCO) and $1 \mathrm{X}$ PEST (GIBCO) at $37^{\circ} \mathrm{C}$ in a $5 \% \mathrm{CO}_{2}$ incubator except for $\mathrm{HCT}-116$, which was cultivated in McCoy’s 5A medium (Sigma-Aldrich). Mycoplasma contamination was excluded for all the cells 
by using a commercially available PCR kit (PromoKine, Heidelberg, Germany).

Stable Transfection

RKO and SW620 cells were transfected by using FuGene HD transfection reagent (Roche Diagnostics Corporation, IN, USA) according to the manufacturer’s instructions. To obtain Livin over-expressing (OE) cells with stable transfection of expression plasmid and the control plasmid (empty vector), cells were selected by Geneticin ( $400 \mu \mathrm{g} / \mathrm{ml}$ for RKO cells, $800 \mu \mathrm{g} / \mathrm{ml}$ for SW620 cells) for 2 weeks (starting at 24 hrs after transfection) and maintained in culture medium supplemented with Geneticin (200 $\mu \mathrm{l} / \mathrm{ml}$ for RKO cells, 400 $\mu \mathrm{g} / \mathrm{ml}$ for SW620 cells).

\section{Western Blot}

The cells were lysed in RIPA buffer ( $150 \mathrm{mM} \mathrm{NaCl}, 2 \%$ Triton, $0.1 \%$ SDS, $50 \mathrm{mM}$ Tris $\mathrm{pH}$ 8.0) containing 1\% Protease Inhibitor Cocktail (Sigma) after transfection. Protein concentrations were determined by BCA Protein Assay (Thermo Fisher, Woburn, MA, USA). Proteins were resolved by electrophoresis on TGX precast 10\% polyacrylamide gels (Bio-Rad, Hercules, CA, USA) and electroblotted to polyvinylidene difluoride membranes (GE healthcare, Piscataway, NJ, USA) and then incubated with block solution (5\% nonfat milk, or 5\% BSA, 0.1\% Tween 20, in TBS). Membranes were incubated with appropriate primary antibodies and then with secondary HRP-conjugated antibodies (DAKO Cytomation, Glostrup, Denmark). Signals were detected by exposure to ECL Hyperfilms (GE healthcare) after treatment with ECL Plus Western Blot Detection System (GE Healthcare). In some experiments, membranes were stripped with Restore ${ }^{\mathrm{TM}}$ Western Blot Stripping Buffer (Thermo Fisher) and reprobed.

The primary antibodies used were: Livin (Goat polyclonal, 1: 3,000) from RnD., Minneapolis, USA; mTOR 
(rabbit polyclonal, 1: 1,500), phosphorylated (Ser 2481) mTOR (rabbit polyclonal, 1:1,500), BCL-2 (rabbit polyclonal, 1: 600), $\beta$-actin (rabbit monoclonal, 1: 10,000), GAPDH (rabbit monoclonal, 1: 10,000) from Cell Signaling Technology., Danvers, MA; p-53 (mouse monoclonal, 1: 1,200), Ki-67 (rabbit monoclonal, 1: 200) from AbCam., Cambridge, UK; Survivin (mouse monoclonal, 1: 800), BAX (rabbit polyclonal, 1: 500), Bcl-XL (mouse monoclonal, 1: 600) from Santa Cruz., Santa Cruz, CA.

\section{WST-1 Assay}

Survival of cells after treatment was quantified by WST-1 assay (Roche) according to the manufacturer’s instructions. Briefly, cells were seeded in 96-well tissue culture plate, in $100 \mu \mathrm{l}$ culture medium. $10 \mu \mathrm{l}$ of WST-1 assay solution was added to each well and the cells were further incubated at $37^{\circ} \mathrm{C}$ for $2-3$ hrs. The absorbance was measured at a wavelength of $450 \mathrm{~nm}$ on a VersaMAX microplate reader (Molecular Devices, Sunnyvale, CA). Untreated cells served as the indicator of $100 \%$ cell viability.

\section{RNAi Knock-down}

Cells were transfected with either Dharmacon Non-Targeting scramble siRNA or ON-TARGETplus ${ }^{\mathrm{R}}$ SMARTpool siRNA against Livin (L-004391-00-5551, Thermo Fisher) by using DharmaFect 2 transfection reagent (Dharmacon) according to the manufacturer' instructions. The transfection mixture consisted of antibiotic-free culture medium and 100 nM siRNA.

\section{DEVDase Activity}

The assay was performed on a VersaMAX plate reader coupled with SOFTMAX software (Molecular Devices) operating in the end-point or kinetic mode at $37{ }^{\circ} \mathrm{C}$. DEVDase acitivity was determined by using colorimetric 
pNA substrates (maximal absorbance at $405 \mathrm{~nm}$ ). Assay buffer was $50 \mathrm{mM}$ Tris, pH 7.4; 0.3\% NP-40, and 10 mM dithiothreitol. Data were recorded every $30 \mathrm{~min}$ for various periods of time as appropriate for each assay.

Immunocytochemistry

Cells were fixed in 4\% paraformaldehyde and permeabilized with $0.1 \%$ Triton X-100 and incubated overnight at $4{ }^{\circ} \mathrm{C}$ with anti-human cleaved caspase-3 antibody (rabbit polyclonal, 1: 200, Cell Signaling Technology), anti-Livin antibody (1: 100, RnD System). EnVision system (DAKO) was used for staining with 3-diaminobenzidine (DAB) as chromogen and hematoxylin as counterstain.

\section{Real Time PCR}

mRNA was extracted from cells using TuboCapture mRNA Preparation Kit (Qiagen, Hilden, Germany), followed by reverse transcription with a High Capacity cDNA Synthesis Kit (Applied Biosystems, Foster city, CA) according the manufacturer's instruction. Real time PCR reaction was performed on the ABI Prism 7500HT or 7900HT Sequence Detection System (Applied Biosystems), using the comparative threshold cycle (Ct) method $(\Delta \Delta \mathrm{Ct})$. The PCR master mix was set up with TaqMan Fast Universal PCR Master Mix (Applied Biosystems). Primers and probes were TaqMan ${ }^{\mathrm{R}}$ Gene Expression Assay for Livin and $\beta$-actin mRNA (Applied biosystems).

\section{Colony Forming Assay}

Log-phase cells were seeded in triplicate in the 6-well plates with $2 \mathrm{ml}$ complete media (500 cells/well), and incubated at $37^{\circ} \mathrm{C}$ in a humidified incubator. Plates were initially examined by light microscope to confirm that only single cells without clumps had been plated. 7-10 days after plating, the colonies were fixed with 4\% 
formaldehyde and stained with 5\% Giemsa. Colonies were visualized with an Olympus IX51 microscope

(Olympus, Japan). The colonies containing more than 50 cells were counted.

Statistic Analysis

To evaluate statistical significance the Student's t-test was performed. The statistic analysis was performed by a statistician unknown of the experiment. Results are given as means standard error of means. All p-values below 0.05 were considered significant.

\section{Results}

Responses to cisplatin of different colon cell lines

To test the effects of cisplatin, we used a panel of colon cancer cell lines including HCT116, RKO, KM12C and SW620 with different concentrations of cisplatin (10 and $20 \mu \mathrm{g} / \mathrm{ml})$ at $24 \mathrm{hrs}$ and $48 \mathrm{hrs}$ post treatment. The viable cells were determined by trypan blue exclusion, and cell numbers were analysed on a Countess automatic cell counter (Sigma). The results showed these cells had different responses to cisplatin (Online Resource 1a). Treatment of RKO and KM12C cells resulted in significant reduction of cell survival. SW620 cells were more resistant to cisplatin because the survival changed only a little after drug addition. And HCT116 cells showed an intermediate response to cisplatin.

To further confirm these results, we used the WST-1 reagent to assay for the cell viability (Fig 1a).

Increasing concentration of cisplatin $(1,5,10,20$ and $40 \mu \mathrm{g} / \mathrm{ml})$ led to decreased cell viability in all cells tested. Again, the results showed RKO and KM12C cells were more sensitive, while SW620 and HCT116 cells were more resistant.

Finally, we determined the cisplatin sensitivity of colon cancer cells by using clonogeneity assay. From 
the results (Online Resource 1b), we could observe a signicant decrease in colony number after addition of cisplatin in RKO and KM12C cells, but this was not the case for SW620 and HCT116 cells. Results of colony number and the survival fraction confirmed the observation (Fig 1b, Online Resource 1c).

From these results, we could conclude RKO and KM12C cells were the most sensitive to cisplatin treatment, followed by HCT116 cells, while the SW620 cells remained the most resistant cells.

Cisplatin induced cell death was related to cell apoptosis

We assayed for caspase-3 activation which is considered as a critical biochemical event in apoptosis cascade [22-23]. We could observe a dose-dependent increase of caspase-3 activity in cisplatin-treated RKO cells (Fig 1c). The increase of caspase- 3 activity was correlated to prolonged incubation time in the kinetic mode. The same increase could be observed in cisplatin-treated SW620 cells. In this cell line, the caspase-3 activity was lower than that in RKO cells which was in good agreement of lower sensitivity of SW620 cells to cisplatin. These results remained till 12 hrs post incubation in the endpoint mode (Online Resource 2). Similar results were also observed for cisplain-treated HCT116 cells, but not for KM12C cells. These results remained constant in our following repeats (data not shown). KM12C cells seemed to have unique biochemical signaling independent of caspase-3 activation. The activation of caspase-3 was further confirmed by the immunohistochemical (IHC) staining by using a monoclonal antibody specific for activated caspase-3 (Fig 1d). Strong cytoplasmic staining could be observed after cisplatin treatment, and was always accompanied by shrinked cell size which is a typical manifestation of cell apoptosis. Finally, we pre-treated colon cancer cells with a caspase-3 inhibitor zDEVDfmk and found this inhibitor could salvage RKO and_SW620 cells from cisplatin induced cell toxicity (Fig 1e). 
Different sensitivity to cisplatin was related to expression level of anti-apoptotic factor Livin

IAP members including Livin have been implicated in chemotherapy resistance in tumor cells [1,4]. Here we tested the relative expression level of Livin in these colon cells by Western Blot (Fig 2a). In these cell lines, Livin expression level was highest in SW620 cells, followed by HCT116, RKO, and KM12C cells in order. The results were confirmed by real time PCR as well (Fig 2b). That seemed to be a relationship between expression of Livin and intrinsic resistance to cisplatin. The higher expression level led to higher resistance, and vice versa.

To further explore the relationship between Livin expression and cisplatin resistance, we treated colon cancer cells with increasing concentrations of cisplatin (10 and $20 \mu \mathrm{g} / \mathrm{ml})$ and determined the expression of Livin before and after cisplatin treatment (Fig 2c). We found expression of Livin increased with increasing dose of cisplatin in SW620, HCT116 and KM12C cells. However in RKO cells which are among the most sensitive cells, the expression hardly changed. We also checked the expression of a panel of apoptosis related factors such as Bcl-2, Bcl-XL, P53, Survivin and Bax, and found most of them remained constant except for P53 whose expression increased with cisplatin treatment. Of notice, HCT116 and RKO cells have wild type P53 while the others are with mutated P53. The intepretation of the observed increase of P53 should be cautious and no conclusion was drawn.

Cisplatin treatment did not change the subcellular localization of Livin A previous report indicated that Livin had both anti- and pro-apoptotic function, which was determined by its different subcellular localization [24]. So we wanted to test the subcellular localization of Livin following cisplatin treatment. The subcellular localization of Livin was detected by immunocytochemistry staining both before and after cisplatin treatment. The expression of Livin was mainly restricted to cytoplasm and the distribution pattern remained the same before and after cisplatin treatment (Fig 3a). To further confirm these 
results, a cytoplasm and nucleus fractionation was performed (Fig 3b). Enrichment of Ki67/MIB-1 in the nucleus fraction and GAPDH in the cytoplasmic fraction indicated the successful separation, and Livin was mainly restricted to the cytoplasmic fraction. These results showed cisplatin treatment did not change the cytoplasmic localization of Livin, nor its anti-apoptotic properties per se.

Cisplatin induced Livin expression sas related to activated mTOR pathway

We pre-treated SW620 cells with a proteosome inhibitor MG132 and found there was actually no effect on Livin expression, either at the concentration of 20 or $40 \mu \mathrm{M}$. Nor did it abrogate cisplatin-indued Livin expression (Fig 4a). Although at these concentrations, there was already significant synergistic cytotoxicity with cisplatin (Fig 4b). We propose ubiqituitin-proteosome pathway might be not so important at least for this cell line under this situation. Next, we used a protein synthesis inhibitor actinomycin D to treat the cells and found this reagent could drastically decrease the Livin expression level (Fig 4c). Interestingly, this inhibition could be reversed by adding of cisplatin. We also used real time PCR to determine the Livin mRNA, and the mRNA level also increased after cisplatin treatment (Fig 4d). These data provided clues cisplatin might induce Livin expression at the transcription or translation level. There was a report showing the regulation of Livin might be related to_the mTOR pathway [25]. Therefore we detected the activation of mTOR pathway by Western blot (Fig 4e). Activated mTOR pathway as shown by elevated phosphorylated AKT (p-AKT), phosphorylated mTOR (p-mTOR), phosphorylated S6K (p-S6K), phosphorylated 4E-BP1 (p-4E-BP1) could be observed along-side an increased expression of Livin after cisplatin treatment in a dose dependent fashion. The total amount of mTOR, S6K and 4E-BP1 remained unchanged, although there was a slight decrease for total AKT and GAPDH. To further confirm cisplatin induced Livin expression was related to the mTOR pathway activation, we used a PI3K-mTOR inhibitor LY294002 to inhibit the activation of mTOR and found this 
inhibitor could abrogate the Livin up-regulation induced by cisplatin (Fig 4f).

Over-expression of Livin led to cisplatin resistance

Our next step was to confirm higher expression of Livin could make cells more resistant to cisplatin. We made stable transfectants of Livin over-expression (OE) from parental RKO and SW620 cells, and the transfectants were confirmed by Western blot (Fig 5a) and real time PCR (Fig 5b). In the following studies, both over-expression transfectants showed higher cell viability to cisplatin than transfectants of empty vector (EV, Fig 5c). Because it was proposed that Livin could inhibit apoptosis by binding and suppressing down-stream caspases [3,4], in an attempt to explore the probable mechanism we assayed the caspase-3 activity of the Livin over-expression transfectants with or without cisplatin treatment (Fig 5d). Less activities were observed from RKO.OE cells both in the presence or absence of cisplatin, compared with RKO.EV cells. For SW620.OE cells, the caspase-3 activity increased less than 2 times while it increased more than 3 times in SW620.EV cells.

Knock-down of Livin rendered cells more sensitive to cisplatin

Our data showed ectopic expression of Livin led to higher cisplatin resistance, in order to further confirm these results we performed knock-down of Livin in RKO and SW620 cells by using siRNA. The knock-down was confirmed by our Western blot (Fig 6a) and real time PCR results (Fig 6b). After knock-down of Livin, the cells showed less survival following cisplatin compared with scramble non-targeting siRNA treated ones (Fig 6c). In addition, cells with Livin knock-down have reduced colony formation capacity compared with scramble siRNA treated counterparts (Fig $6 \mathrm{~d}$ ).

\section{Discussion}


Livin has been considered as a critical factor contributing to progression, poor prognosis and therapeutic resistance in various types of tumors. Due to its distinctive enrichment in tumors but none or low expression in normal tissue, Livin has been proposed as a potential therapeutic target [19]. Several reports helped to expand its expression profile to variant tumors such as melanoma, leukemias, bladder, breast, cervical, nasopharyngeal and lung cancer [5-8]. However, there are only limited reports regarding its expression in CRC except some preliminary studies [17-21]. Previously, Livin expression was described in only 3 colon cancer cell lines (LoVo, HCT-8 and SW620). Here we detected Livin expression in all eight colon cancer cell lines by Western Blot (HCT116, RKO, KM12C, KM12L4A, KM12SM, SW480 and SW620, Online resource 3). The extensive expression of Livin in colon cancer cells implied Livin may be of importance in CRC.

Previous reports demonstrated that Livin contributed to resistance to fluorouracil, etoposide, and vincristine for tumor cells, but no studies were intended to explore the relationship between Livin expression and resistance to platinum. Platinum remains the mainstay therapeutic reagent for most of the solid tumors. In the current study, we determined the sensitivity to cisplatin of four colon cancer lines by using different methods. We concluded RKO and KM12C cells were the most sensitive, followed by HCT116 cells, while the SW620 cells remained as the most resistant ones. We also determined the type of cell death induced by cisplatin was related to apoptosis, except in KM12C cells where other mechanisms may be involved as well. Of notice, other reports also indicated KM12C cells had a distinctive type of cell death beyond apoptosis [26]. The intriguing findings that different Livin expression levels were highly correlated to cisplatin resistance led us to suppose that Livin may play a role in mediating cisplatin resistance. Our next experiments showed that the expression of Livin increased when cells were treated with increasing doses of cisplatin. This may provide further evidence to support our hypothesis that Livin contributed to cisplatin resistance. We transfected Livin into RKO and SW620 cells and found the over-expressed Livin conferred the cells with resistance to cisplatin 
compared with the vector-transfected ones. Finally we knocked down the endogenous Livin by siRNA, and then the cells became more vulnerable to cisplatin. These data indicate that Livin might be a critical factor for cisplatin resistance for colon cancer cells.

There are controversies regarding the mechanism by which Livin inhibits apoptosis. Initially it was thought Livin could bind and suppress the down-stream effector caspase-3, or 9, which was a canonical mechanism used by other IAPs such as XIAP [3]. However, later experiments failed to prove this notion. Vucic D et al reported Livin could merely weakly inhibit caspase-9 activity with inhibition constant $K i$ approximately 3-5 $\mu \mathrm{M}$. Also, it was argued that Livin might regulate apoptosis by sequestering SMAC from XIAP [27]. In our study, we found Livin over-expression led to resistance to cisplatin together with reduced caspase-3 activity. Our data indicated cisplatin-resistance mediated by Livin might be involved with caspase inhibition by Livin, but the question of whether caspase-3 was inhibited by Livin directly or indirectly is awaiting for further studies.

The mTOR protein kinase in eukaryotic cells has emerged as a critical growth-control node, receiving stimulatory signals from PI3K and ras as well as nutrient input [28]. mTOR signaling pathway couples nutrient and energy to the execution of cell growth and division [29]. mTOR kinase can regulate the down-stream kinases such as S6K, Akt and 4E-BP1 and control gene expression thereby. Previous study showed an increased Akt activity after treatment with cisplatin in colon cancer cells HT29 [30]. This report was in line with the current results. In our study, we also found a dramatic increase in the activity of mTOR pathway molecules such as mTOR, S6K and 4E-BP1 when the colon cancer cells SW620 were treated with cisplatin. The activation of the mTOR pathway was linked to the induced Livin expression by cisplatin. These results led us to suspect the increased expression of Livin might be a down-stream event of mTOR activation.

In the current study, we failed to show the regulation of Livin expression by ubiquitin-proteosome 
pathway in SW620 cells although there was a report where the redundancy of Livin was dependent on its degradation by proteosome [13]. Neither could we find this regulation in another colon cancer cell line HCT116 (data not shown). The mechanism behind this discrepancy between the report and our study remains elusive at present, but we speculated that this was partly attributed to the low expression level of Livin in colon cancer cells compared with HeLa cervical cancer cells or melanoma cells (data not shown). Livin may have a different regulation pattern in different types of cancers. We found that cisplatin induced Livin expression in most of the colon cancer cells and in an attempt to explore the possible mechanism, and the increase of Livin was at the transcription or translation level. Furthermore, we could detect an increase of Livin mRNA after cisplatin treatment. Also the inhibition of PI3K-mTOR pathway could partially abrogate the increase of Livin expression. Taken together, we reasoned the increase of Livin by cisplatin may be at both transcription and translation level.

In summary, we find a high prevalence of Livin expression in colon cancer cells and its expression is strongly related to the resistance to cisplatin. Livin expression increases following cisplatin treatment, and the regulation is enhanced from both transcription and translation level. Forced over-expression of Livin increases the cisplatin resistance, while knock-down sensitizes cancer cells to cisplatin. Our study along with others highlighted the potential of Livin for cancer therapy in colon cancer.

\section{Acknowledgements}

We thank Prof. IJ Fidler from Anderson Cancer Center for his generosity of providing the KM12C cells, Dr.

Chun Wang for the statistical analysis, and Dr. David Hinselwood for linguistic revision of the manuscript. This study was supported by grants from National Natural Science Fund of China (30901756), Doctoral Fund of Ministry of Education of China (20090181120100), Swedish Cancer Foundation, Swedish Research Council and the Health Research Council in the South-East of Sweden. 


\section{Conflict of interest}

The authors declare that they have no conflict of interest. 


\section{References}

1. Gyrd-Hansen M, Meier P. IAPs: from caspase inhibitors to modulators of NF-kappaB, inflammation and cancer. Nat Rev Cancer. 2010;10:561-74.

2. Lin JH, Deng G, Huang Q, Morser J. KIAP, a novel member of the inhibitor of apoptosis protein family. Biochem Biophys Res Commun. 2000;279:820-31.

3. Vucic D, Stennicke HR, Pisabarro MT, Salvesen GS, Dixit VM. ML-IAP, a novel inhibitor of apoptosis that is preferentially expressed in human melanomas. Curr Biol. 2000;10:1359-66.

4. Kasof GM, Gomes BC. Livin, a novel inhibitor of apoptosis protein family member. J Biol Chem. 2001;276:3238-46.

5. Tanabe H, Yagihashi A, Tsuji N, Shijubo Y, Abe S, Watanabe N. Expression of survivin mRNA and livin mRNA in non-small-cell lung cancer. Lung Cancer. 2004;46:299-304.

6. Gazzaniga P, Gradilone A, Giuliani L, et al. Expression and prognostic significance of LIVIN, SURVIVIN and other apoptosis-related genes in the progression of superficial bladder cancer. Ann Oncol. 2003;14:85-90.

7. Choi J, Hwang YK, Sung KW, et al. Expression of Livin, an antiapoptotic protein, is an independent favorable prognostic factor in childhood acute lymphoblastic leukemia. Blood. 2007;109:471-7.

8. Xiang Y, Yao H, Wang S. et al. Prognostic value of Survivin and Livin in nasopharyngeal carcinoma. Laryngoscopy. 2006;116:126-30.

9. Gong J, Chen N, Zhou Q, Yang B, Wang Y, Wang X. Melanoma inhibitor of apoptosis protein is expressed differentially in melanoma and melanocytic naevus, but similarly in primary and metastatic melanomas. J Clin Pathol. 2005;58:1081-5.

10. Ashhab Y, Alian A, Polliack A, Panet A, Ben-Yehuda D. Two splicing variants of a new inhibitor of 
apoptosis gene with different biological properties and tissue distribution pattern. FEBS Lett. 2001;495:56-60.

11. Duckett CS. IAP proteins: sticking it to Smac. Biochem J. 2005;385:e1-2.

12. Sanna MG, da Silva Correia J, Ducrey O. et al. IAP suppression of apoptosis involves distinct mechanisms: the TAK1/JNK1 signaling cascade and caspase inhibition. Mol Cell Biol. 2002;22: 1754-66.

13. Ma L, Huang $\mathrm{Y}$, Song $\mathrm{Z}$ et al. Livin promotes Smac/DIABLO degradation by ubiquitin-proteasome pathway. Cell Death Differ. 2006;13:2079-88.

14. Jemal A, Siegel R, Xu J, Ward E. Cancer statistics, 2010. CA Cancer J Clin. 2010;60:277-300.

15. Meza R, Jeon J, Renehan AG, Luebeck EG. Colorectal cancer incidence trends in the United States and United kingdom: evidence of right- to left-sided biological gradients with implications for screening. Cancer Res. 2010;70:5419-9.

16. Siddik ZH. Cisplatin: mode of cytotoxic action and molecular basis of resistance. Oncogene. 2003;22:7265-79.

17. Endo T, Abe S, Seidlar HB, et al. Expression of IAP family proteins in colon cancers from patients with different age groups. Cancer Immunol Immunother. 2004;53:770-6.

18. Takeuchi H, Kim J, Fujimoto A, et al. X-Linked inhibitor of apoptosis protein expression level in colorectal cancer is regulated by hepatocyte growth factor/C-met pathway via Akt signaling. Clin Cancer Res. 2005;11:7621-8.

19. Wang R, Lin F, Wang X, et al. Silencing Livin gene expression to inhibit proliferation and enhance chemosensitivity in tumor cells. Cancer Gene Ther. 2008;15:402-12.

20. Wang X, Xu J, Ju S, Ni H, Zhu J, Wang H. Livin gene plays a role in drug resistance of colon cancer cells. Clin Biochem. 2010;43:655-60. 
21. Slagsvold JE, Pettersen CH, Størvold GL, Follestad T, Krokan HE, Schønberg SA. DHA alters expression of target proteins of cancer therapy in chemotherapy resistant SW620 colon cancer cells. Nutr Cancer. 2010;62:611-21.

22. Hanahan D, Weinberg RA. The hallmarks of cancer. Cell. 2000;100:57-70.

23. Taylor RC, Cullen SP, Martin SJ. Apoptosis: controlled demolition at the cellular level. Nat Rev Mol Cell Biol. 2008;9:231-41.

24. Nachmias B, Lazar I, Elmalech M, et al. Subcellular localization determines the delicate balance between the anti- and pro-apoptotic activity of Livin. Apoptosis. 2007;12:1129-42.

25. Yan B, Kong M, Chen S, Chen YH. VEGF stimulation enhances Livin protein synthesis through mTOR signaling. J Cell Biochem. 2010;111:1114-24.

26. Hostein I, Robertson D, DiStefano F, Workman P, Clarke PS. Inhibition of signal transduction by the Hsp90 inhibitor 17-allylamino-17-demethoxygeldanamycin results in cytostasis and apoptosis. Cancer Res. 2001;61:4003-9.

27. Vucic D, Franklin MC, Wallweber HJ, et al. Fairbrother, Engineering ML-IAP to produce an extraordinarily potent caspase 9 inhibitor: implications for Smac-dependent anti-apoptotic activity of ML-IAP. Biochem J. 2005;385:11-20.

28. Shaw RJ, Cantley LC. Ras, PI(3)K and mTOR signalling controls tumour cell growth. Nature. 2006;441:424-30.

29. Zoncu R, Efeyan A, Sabatini DM. mTOR: from growth signal integration to cancer, diabetes and ageing. Nat Rev Mol Cell Biol. 2011;12:21-35.

30. Fernández de Mattos S, Villalonga P, Clardy J, Lam EW. FOXO3a mediates the cytotoxic effects of cisplatin in colon cancer cells. Mol Cancer Ther. 2008;7:3237-46. 


\section{Legends to figures}
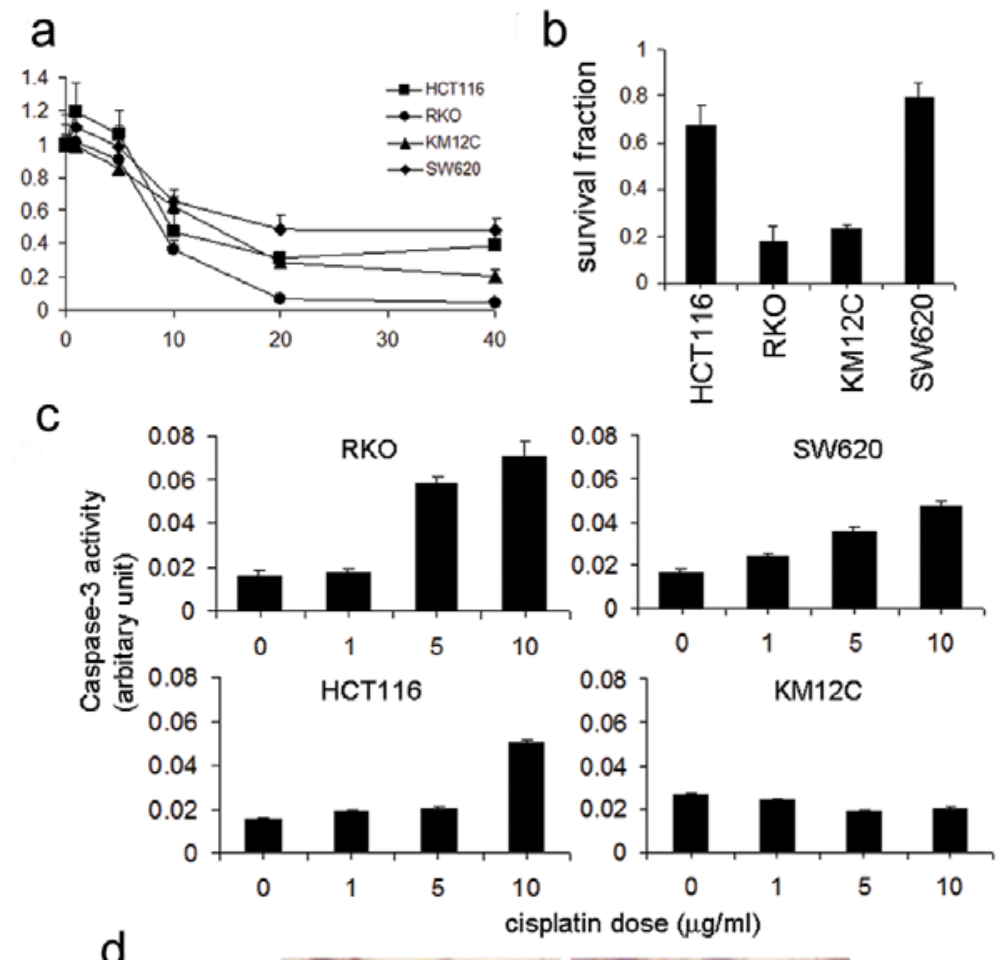

d
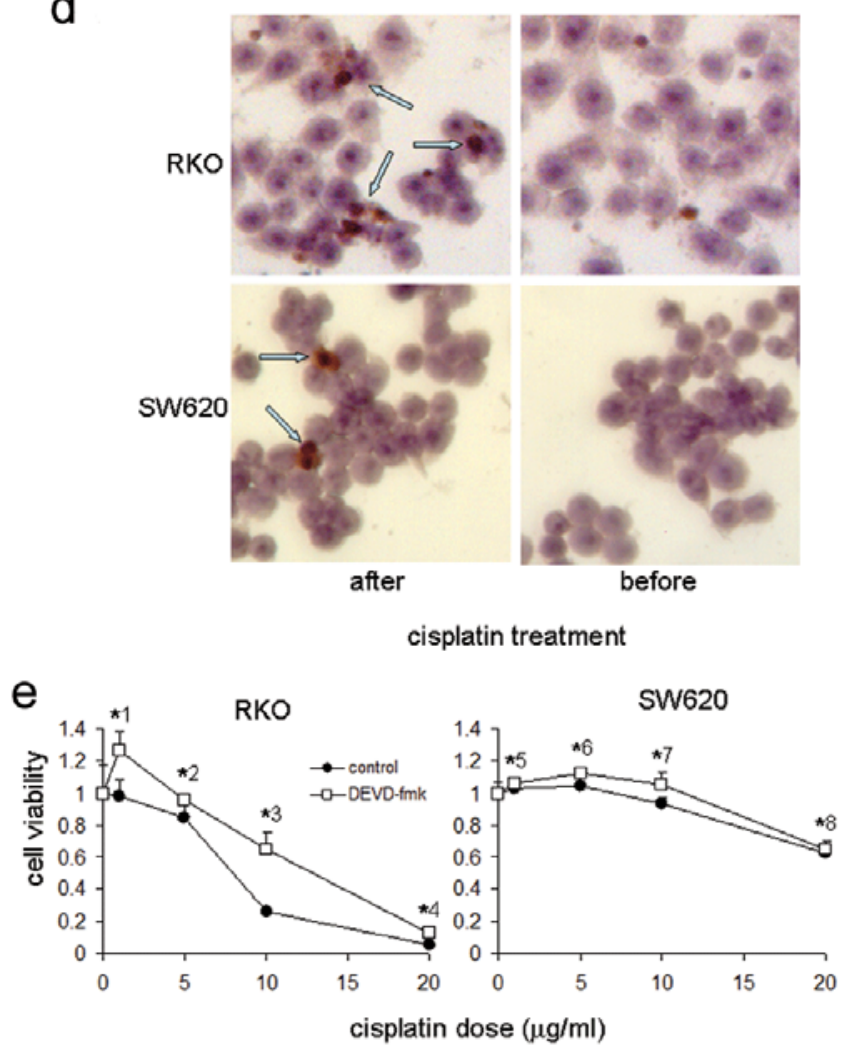

Figure 1 
Fig. 1 Different responses to cisplatin in colon cancer cells was related to apoptosis. a Colon cancer cells (HCT116, RKO, KM12C and SW620) were treated with cisplatin at an increasing concentration (1, 5, 10, and 20 $\mu \mathrm{g} / \mathrm{ml}$ ) for 24 hrs and then subjected to WST-1 agent assay. The cell survival was expressed relative to those without cisplatin treatment which was defined as 100 percent. b The cells were treated with or without cisplatin and the survival fraction was calculated as: colony number/500 (total cell number seeded) $\times 100 \%$. c Colon cancer cells were treated with increasing concentration of cisplatin $(1,5,10,20 \mu \mathrm{g} / \mathrm{ml})$ for 24 hrs and were harvested and lysed as described in the Materials and Methods. The lysates were detected for caspase-3 activity in the end-point mode at 12 hrs after incubation. d Immunocytochemistry with a monoclonal antibody specific for the activated caspase-3 was shown ( $\times$ 400, arrow indicated the activated caspase-3 in RKO and SW620 cells undergoing apoptosis after cisplatin treatment). The inhibitor for DEVDase z-DEVDfmk reversed partially the cytotoxicity induced by cisplatin for RKO and SW620 cells (E, p values: *1=0.010, *2=0.068, *3<0.001, $* 4<0.001, * 5=0.060, * 6=0.019, * 7=0.043, * 8=0.416)$ 
a

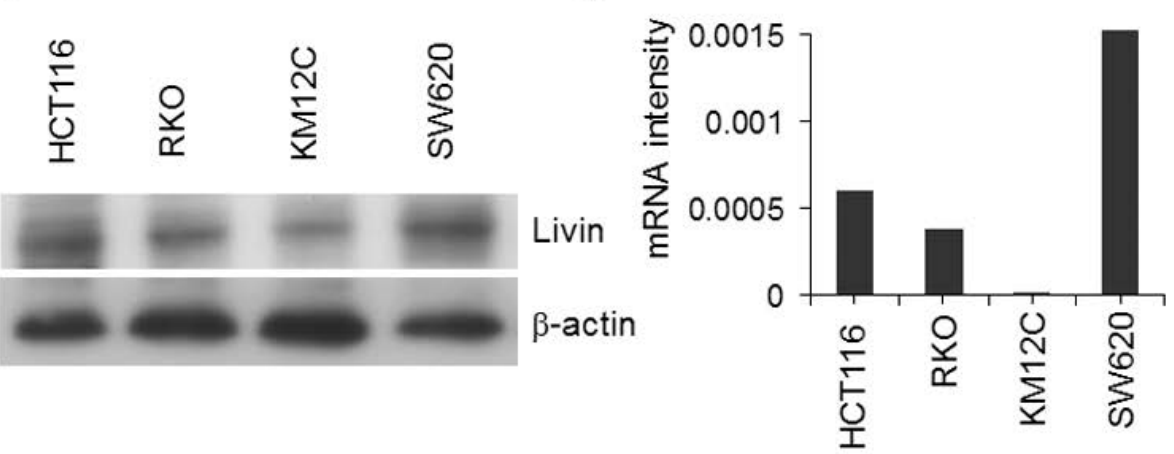

C

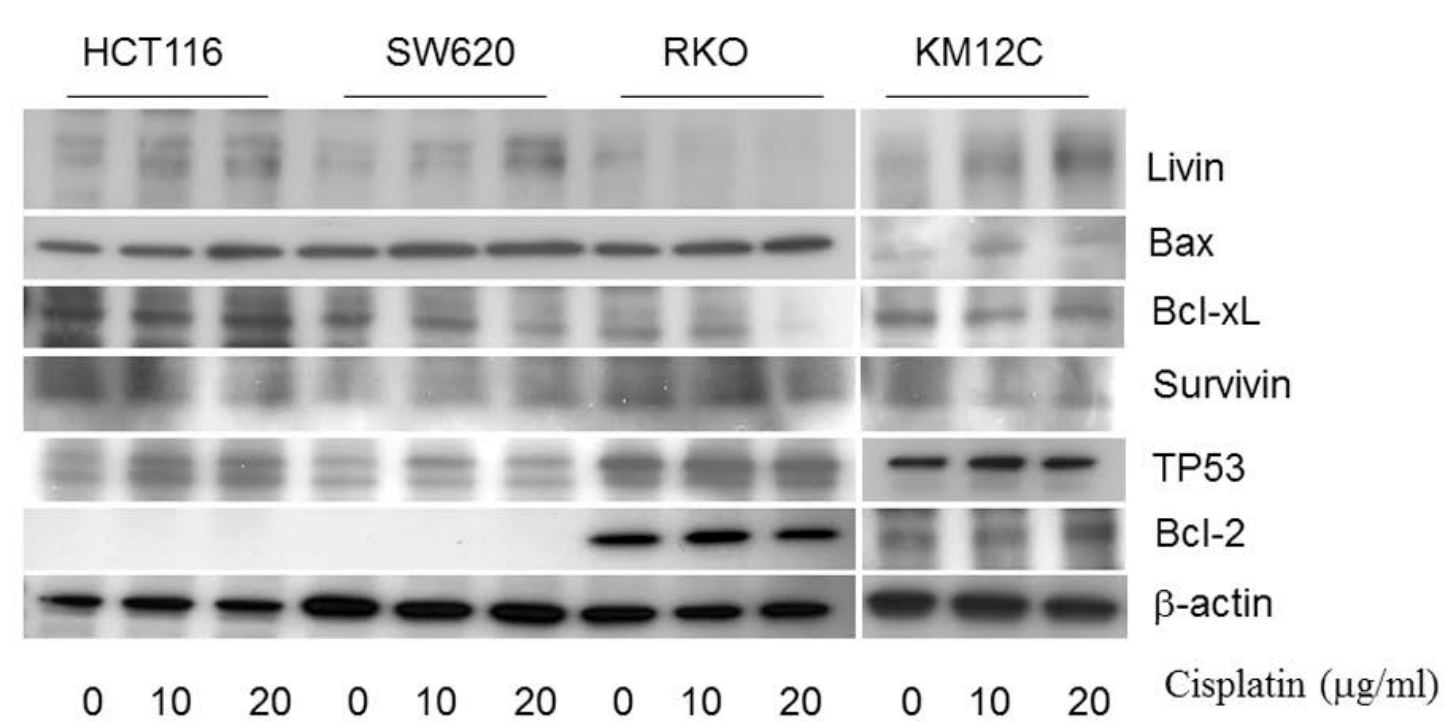

Figure 2

Fig. 2 The expression level of Livin was related to cisplatin resistance in colon cancer cells. The expression level of Livin in colon cancer cells was determined by Western blot a and real time PCR $\mathbf{b}$. c The expression level of a panel of apoptosis related factors was determined by Western blot after cisplatin treatment 
a
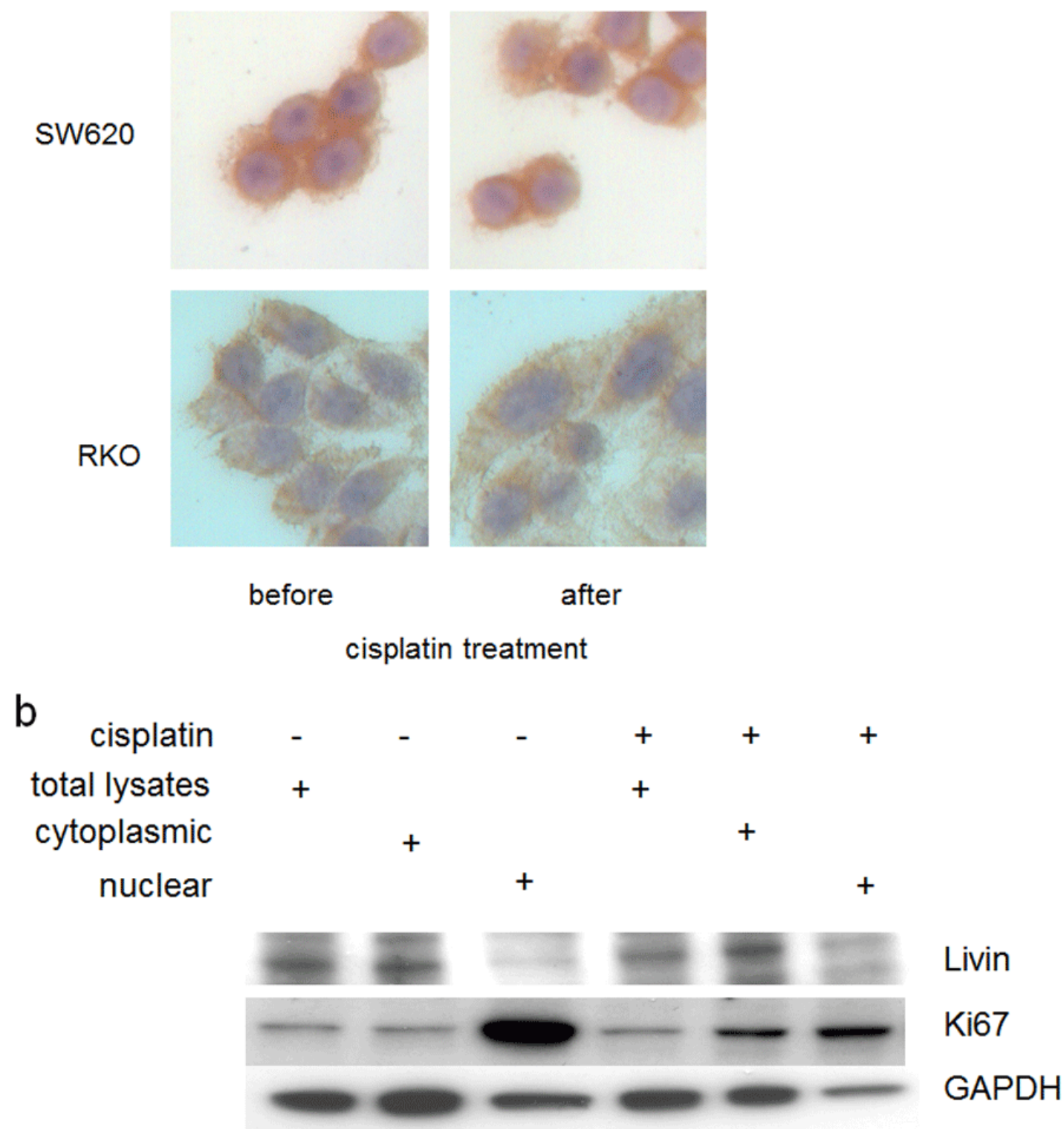

Figure 3

Fig. 3 The sub-cellular localization of Livin did not change after cisplatin treatment. a The sub-cellular localization of Livin in RKO and SW620 cells was detected by immunocytochemistry both before and after cisplatin treatment $(\times 400)$. b Nuclear/cytoplasmic fractionation was performed and Livin was found to be enriched in the cytoplasmic fraction both before and after cisplatin treatment 


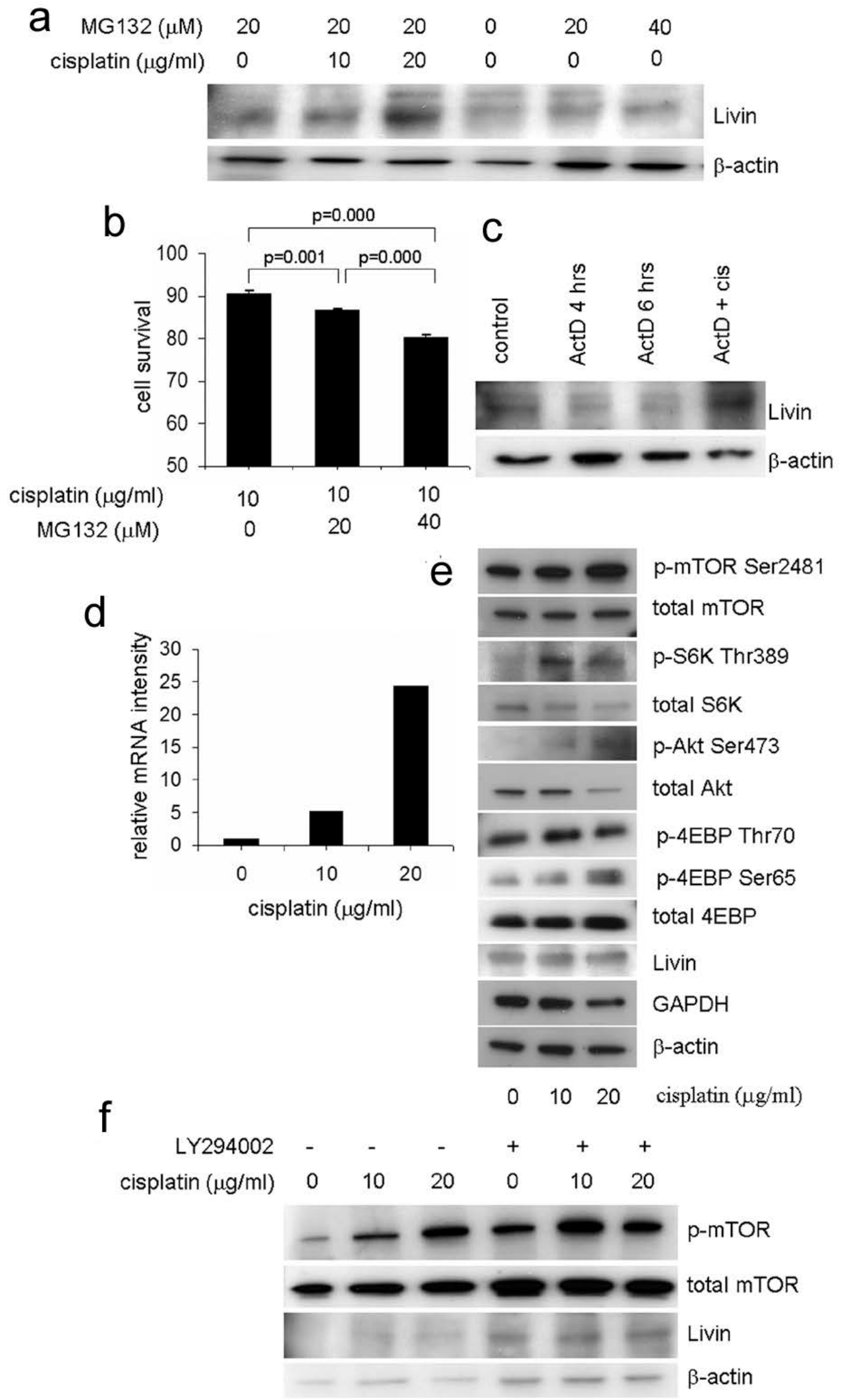

Figure 4 
Fig. 4 The up-regulation of Livin by cisplatin treatment was related to mTOR pathway activation in colon cancer cells. a SW620 cells were treated with a proteosome inhibitor MG132 in the presence or absence of cisplatin. The expression of Livin was detected by Western blot. b At the concentration of $20 \mu \mathrm{M}$ which we used in the experiment above, MG132 significantly enhanced the cytotoxicity of cisplatin. c The inhibitor for RNA synthesis, Actinomycin D, severely reduced the expression of Livin protein in a time-dependent manner while co-incubation with cisplatin could restore the expression of Livin. d The increase of Livin mRNA could be detected by real time PCR after cisplatin treatment. e Cisplatin treatment led to increased phosphorylation of mTOR, S6K, Akt and 4E-BP1 along the mTOR pathway, together with an up-regulation of Livin. $\beta$-actin was loaded as an internal control. f Treatment with the PI3K-mTOR inhibitor LY294002 could reduce the activation of mTOR and up-regulation of Livin 
a

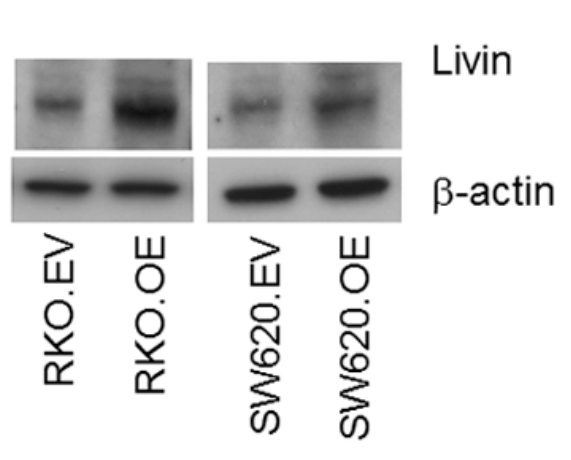

C

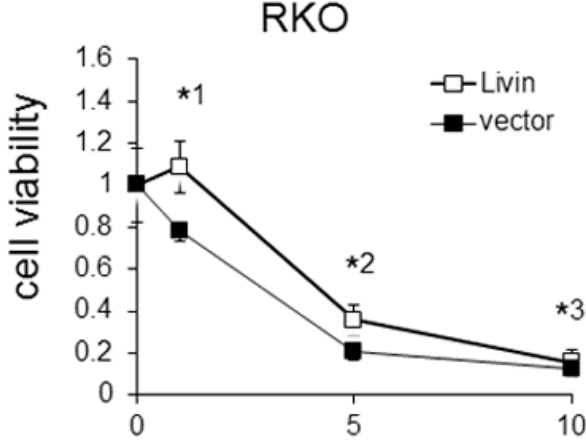

b

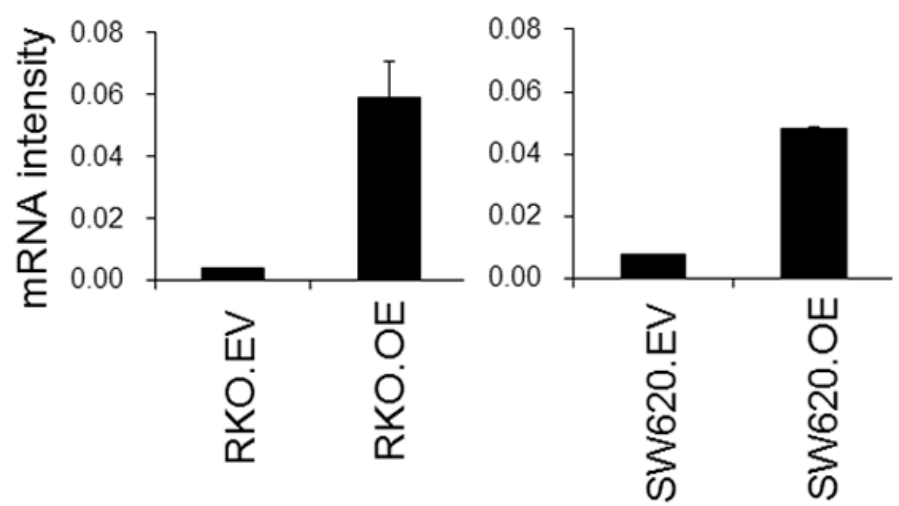

cisplatin dose $(\mu \mathrm{g} / \mathrm{ml})$
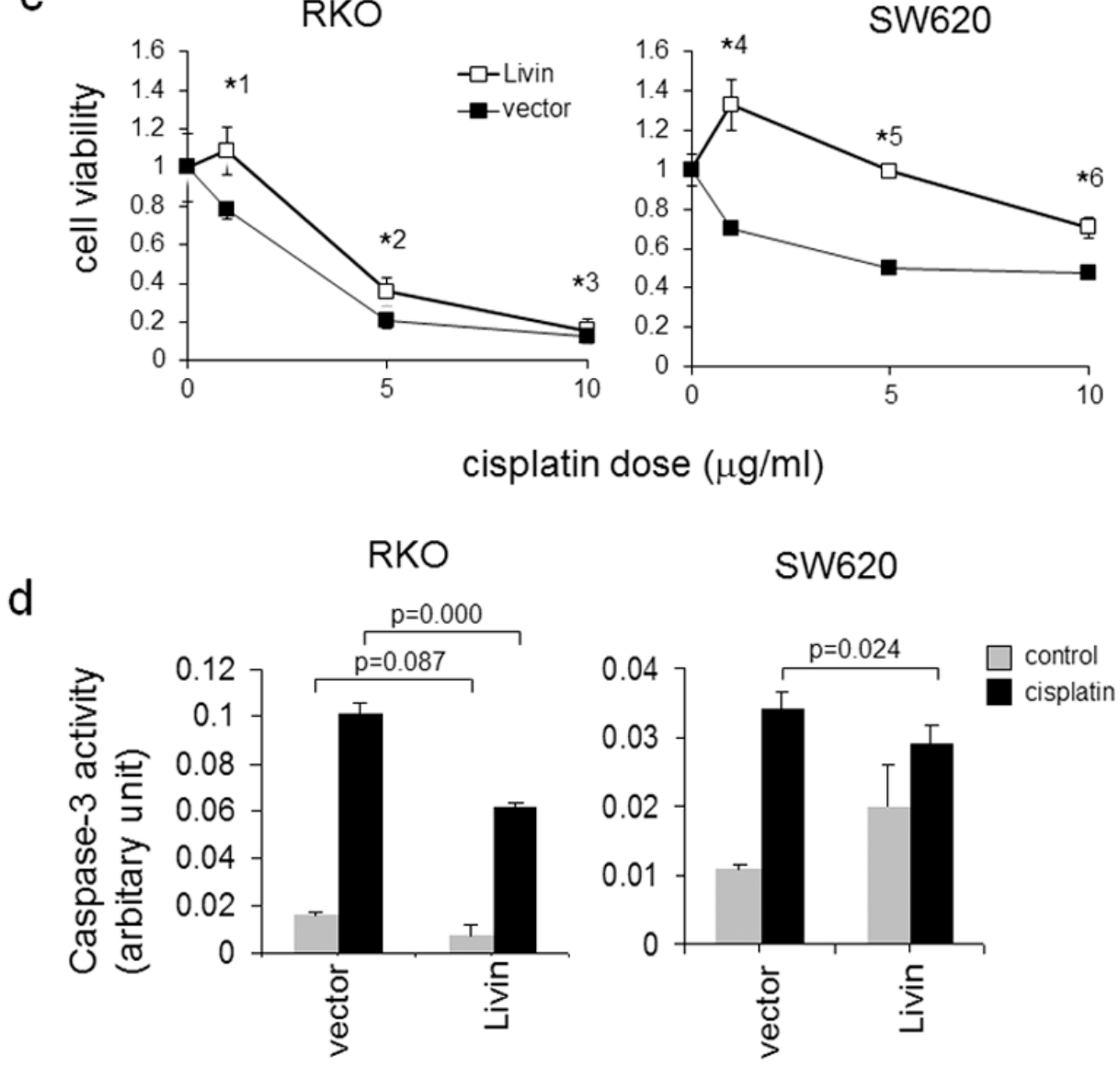

SW620

Figure 5

Fig. 5 Over-expression of Livin in colon cancer cells conferred ressistance to cisplatin. Over-expression of Livin in RKO and SW620 cells was confirmed by Western blot a and real time PCR b. c Cells with stable transfection of Livin had higher survival when treated with cisplatin, compared with vector-transfected ones ( $\mathrm{p}$ values: $* 1=0.004, * 2=0.016, * 3=0.445, * 4<0.001, * 5<0.001, * 6<0.001)$. The cell survival was determined by WST-1 assay. d Cells stably transfected with Livin had a lower caspase-3 activity after cisplatin treatment 
a

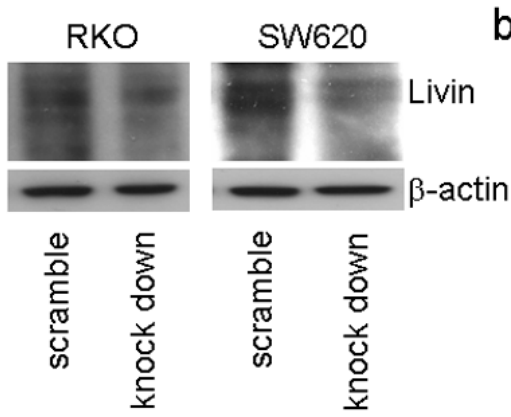

C

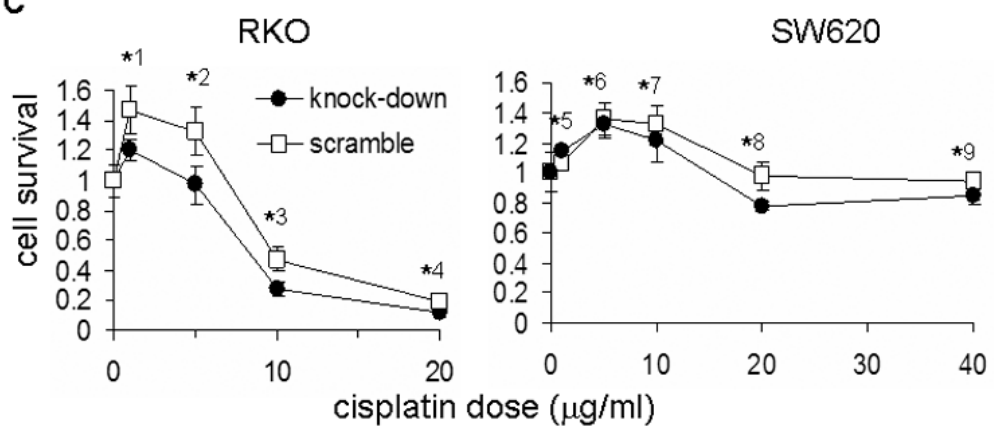

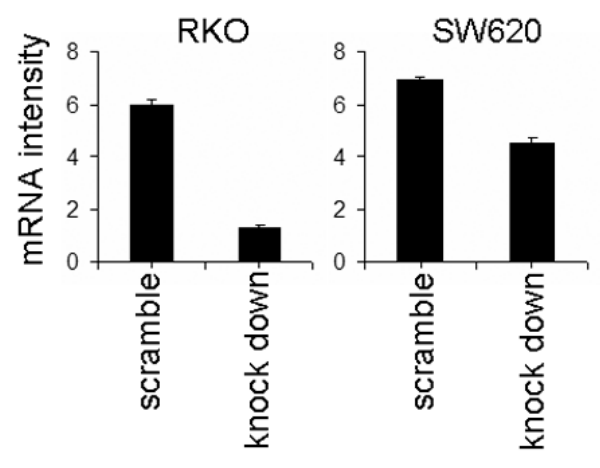

SW620 d

scramble

knock down

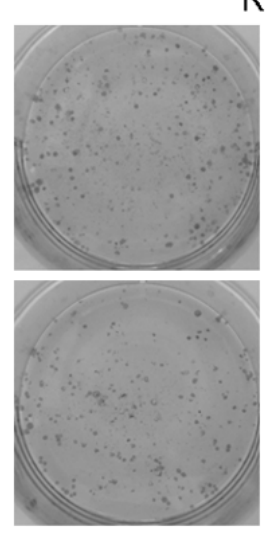

ธั口

RKO
RKO
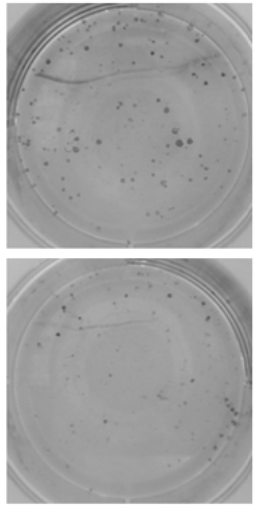

京
SW620
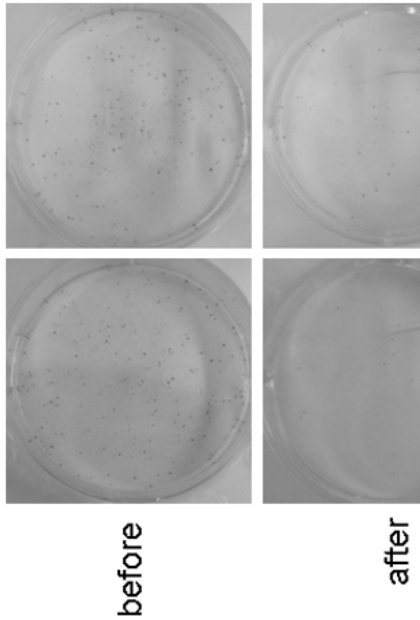

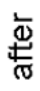

cisplatin treatment

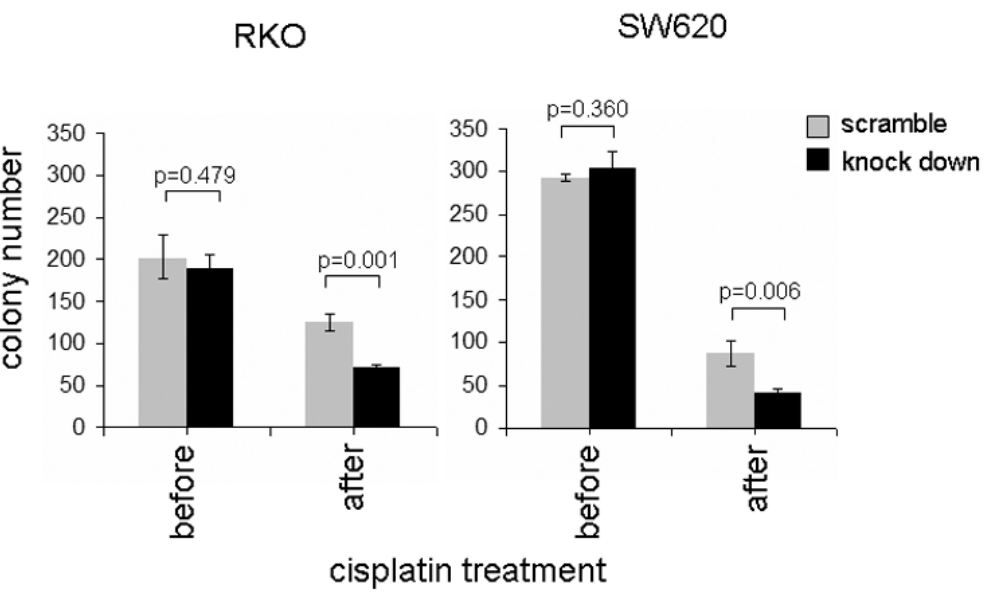

Figure 6 
Fig. 6 Knock-down of Livin rendered the colon cancer cells more sensitive to cisplatin. Knock-down of Livn in RKO and SW620 cells was confirmed by Western blot a and real time PCR b. c Cells with Livin knock-down showed lower survival in WST-1 assay when treated with cisplatin, compared with sramble siRNA transfected ones (p values: $* 1=0.005, * 2=0.275, * 3=0.005, * 4=0.024, * 5=0.010, * 6=0.640, * 7=0.329, * 8=0.042, * 9=0.020)$. d Also, cells with Livin knock-down formed less colonies after cisplatin treatment (upper). The colony number and p values were shown (lower) 

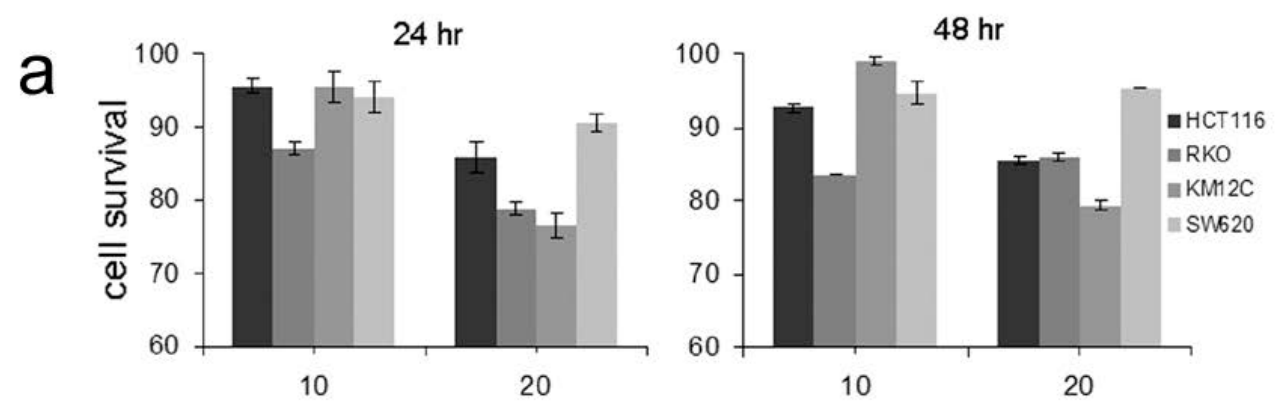

b
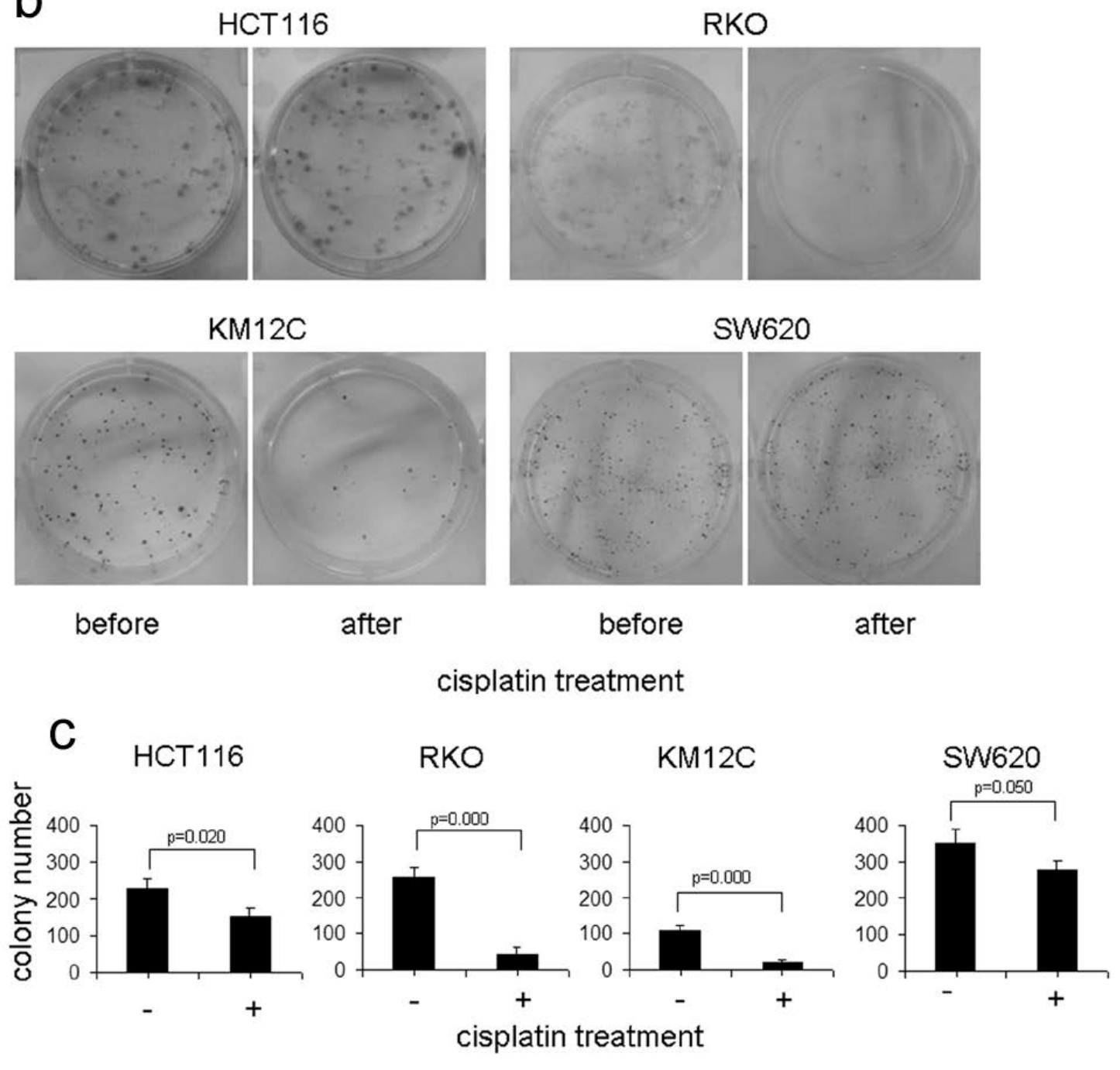

\section{Online Resnurre 1}

Online Resource 1 Different responses to cisplatin in colon cancer cells a Colon cancer cells (HCT116, RKO, KM12C and SW620) were treated with cisplatin at the concentration of $10 \mu \mathrm{g} / \mathrm{ml}$ or $20 \mu \mathrm{g} / \mathrm{ml}$ for 24 or $48 \mathrm{hrs}$. The cell viability was determined by trypan blue exclusion and viable cells were counted on an automatic cell counter. b The cells were treated with cisplatin $(1 \mu \mathrm{g} / \mathrm{ml})$ for $6 \mathrm{hrs}$ and seeded to 6-well-plate, 500 cells each well. 7-10 days later, the colonies were stained with Giemsa and observed under the microscope. $\mathbf{c}$ The colony numbers were recorded for each cell line 


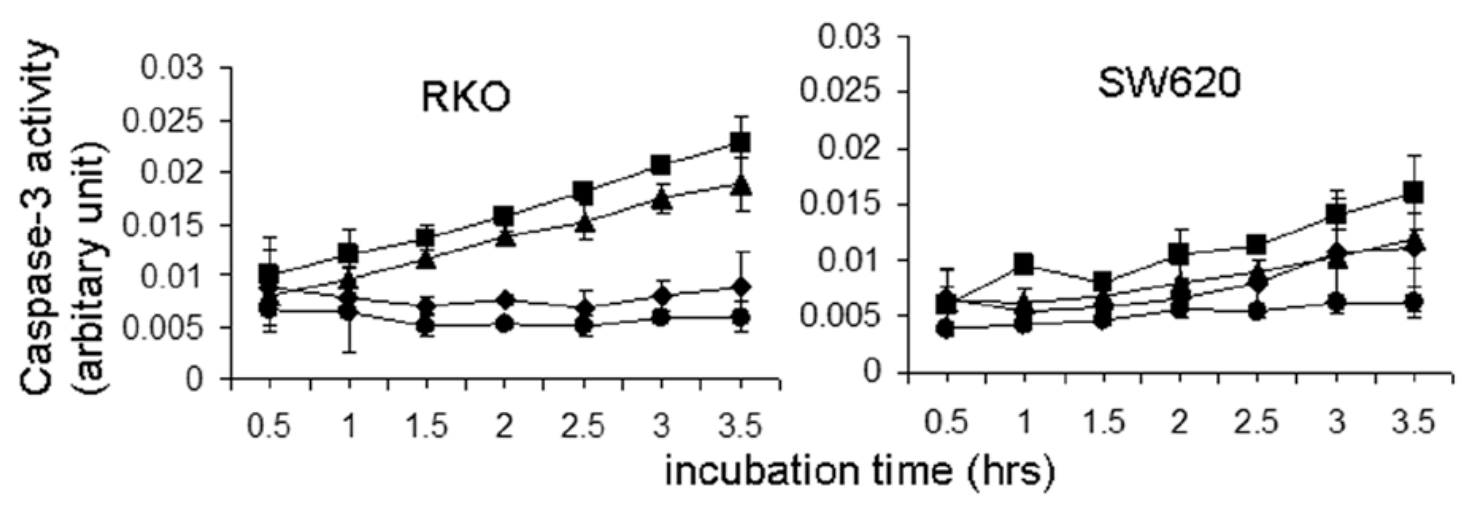

\section{Online Resource 2}

Online Resource 2 Caspase-3 activation in cisplatin-treated colon cancer cells. RKO and SW620 cells were treated with increasing concentration of cisplatin $(1,5,10,20 \mu \mathrm{g} / \mathrm{ml})$ for $24 \mathrm{hrs}$. The lysates were detected for caspase-3 activity in the kinetic mode where the data were collected every $30 \mathrm{~min}$

Online Resource 3 All the 8 colon cancer cell lines had Livin expression as detected by Western blot 